\title{
Genealogi Kajian Hadis Ulama al-Banjari
}

\author{
Hanafi Hanafi \\ Magister UIN Jakarta \\ hanafirai71@gmail.com
}

\begin{abstract}
Since the $16^{\text {th }}$ century, Middle East became a scientific destination for the scholars of Nusantara. The network of Middle Eastern scholars has contributed greatly to the development of various Islamic intellectual traditions in the archipelago, even the case happened in Banjar society. In the process of transmitting scholars, the scholars of al-Banjari (scholars from Banjar, South Kalimantan) are heavily influenced by Islamic ideas derived therein, including kalam, jurisprudence, tasawwuf, and hadith studies. This article will prove to what extend the influence of Middle Eastern scholars on the development of intellectual traditions of al-Banjari scholars in the study of hadith is. The research method in this paper is by reading the primary sources, in the form of Hadith texts by al-Banjari scholars, and then the genealogy of the sanad and their Hadith diplomas connected with the scholars of hadith study in the Middle East. The reading of the sanad and the certificate will prove that their scholarship is connected to authoritative scholars of hadith. Al-Banjari scholars who became the research object is a scholar from the tribe of Banjar which has a script in the field of hadith or hadith study using Arabic or Malay Arabic. From the standardization used, seven scholars became the object of the research, namely Muhammad Arsyad al-Banjari, Muhammad Kasyful Anwar, Muhammad Anang Sya'rani Arif, Abdul Wahid, Muhammad Syukeri Unus, Fahmi Zamzam, and Muhammad Nurdin Marbu.
\end{abstract}

Keywords: Al-Banjari Scholars, Scholars' network, hadith study, Middle East, Banjar.

\begin{abstract}
Abstrak
Timur Tengah menjadi destinasi keilmuan bagi para Ulama Nusantara sejak abad ke-16. Jaringan ulama Timur Tengah mempunyai andil besar dalam mengembangkan aneka ragam tradisi intelektual keislaman di Nusantara. Pun begitu juga yang terjadi di masyarakat Banjar. Dalam proses transmisi keilmuan, ulama al-Banjari (ulama yang berasal dari Banjar, Kalimantan Selatan) banyak sekali terpengaruhi oleh pemikiranpemikiran keislaman yang berasal dari sana, termasuk dalam pemikiran kalam, fikih, tasawuf, dan kajian hadis. Dalam artikel ini akan membuktikan sejauh mana pengaruh ulama Timur Tengah terhadap pengembangan tradisi intelektual ulama al-Banjari dalam kajian hadis. Metode penelitian dalam makalah ini adalah dengan cara membaca sumbersumber primer, berupa naskah-naskah hadis karya ulama al-Banjari, kemudian silsilah
\end{abstract}


Millatī, Journal of Islamic Studies and Humanities, Vol. 2, No. 2, Des. 2017: 169-194

sanad dan ijazah hadis mereka yang terhubung dengan ulama hadis di Timur Tengah. Pembacaan terhadap sanad dan ijazah tersebut akan membuktikan bahwa keilmuan hadis mereka terhubung kepada para ulama hadis yang otoritatif. Ulama al-Banjari yang masuk sebagai objek penelitian disini adalah ulama yang berasal dari suku Banjar, mempunyai naskah dibidang hadis, atau kajian hadis yang berbahasa Arab atau bahasa Arab Melayu. Dari standarisasi yang digunakan tersebut, ditemukan tujuh ulama yang masuk sebagai objek penelitian, Muhammad Arsyad al-Banjari, Muhammad Kasyful Anwar, Muhammad Anang Sya'rani Arif, Abdul Wahid, Muhammad Syukeri Unus, Fahmi Zamzam, dan Muhammad Nurdin Marbu.

Katakunci: Ulama al-Banjari, jaringan Ulama, kajian hadis, Timur Tengah, Banjar.

\section{Pendahuluan}

Mayoritas pakar sejarah hampir sepakat berkesimpulan bahwa Islam yang datang ke Nusantara pada permulaan abad ke-13 bercorak sufistik ${ }^{1}$. Hal ini dibuktikan dengan banyaknya warisan intelektual ulama Nusantara dalam kajian tasawuf yang beraneka ragam coraknya. Secara kronologis, ulama yang pertama kali merintis penulisan kitab tasawuf dalam tulisan Jawi adalah Hamzah al-Fansuri dengan karyanya Sharah al-Ashiqin. Model tasawuf yang dikembangkan oleh al-Fansuri dan muridnya Shamsudiin al-Sumatrani cendrung kepada model tasawuf falsafah dengan aliran wujudiyah yang dikembangkan oleh Ibn 'Arabi ( w. 1240 M), Abu Mansur al-Hallaj (w. 922 M), dan tokoh sejenisnya. Asrar 'Arifin karangan al-Fansuri dan Jawhar al-Haqa'iq karya al-Sumatrani, dominasi paham wujudiyah sangat kental dan dan begitu mendominasi. Namun paham ini mendapat penolakan dari tokoh tasawuf neo-sufisme sesudahnya semisal Nur al-din al-Raniri, 'Abd al-Ra'uf Singkel dan Yusuf al-Makassari. ${ }^{2}$

Hal yang sama juga terjadi di masyarakat Banjar. Pola keislaman masyarakat Banjar juga sangat identik dengan nuansa sufistik. Pada awal abad 17 sampai awal abad ke-18 $\mathrm{M}$ islamisasi terjadi lewat corak sufistik, tepatnya tasawuf falsafi. Nama-nama semisal Syeikh Ahmad Shams al-Din al-Banjari di Martapura, Syeikh

${ }^{1}$ John O. Voll, "Neo-Sufism: Reconsidered Again" Canadian Journal of African Studies, Vol. 42, No. 2/3 (2008), 314-315. Diakses pada tanggal 1 Mei 2016 melalui : http://www.jstor.org/ stable/40380170. Lihat juga Azyumardi Azra, Historiografi Islam Kontemporer, Wacana Aktualitas dan Aktor Sejarah, (Jakarta: Gramedia Pustaka Utama, 2002), h. 120.

${ }^{2}$ Khader Ahmad, "Autoriti Hadith dalam Kitab Tasawuf Tulisan Jawi: Satu Kajian Terhadap Kitab Hidayah al-Salikin”, Journal of al-Qur'an E Hadith Al-Bayan, Vol. 5, No. 10, (2007), h. 98-99. 
Siraj al-Huda atau Datu Sanggul, Datu Suban, dan Datu Nurayya yang berada di Kawasan Rantau. Di Daerah Negara dilakukan oleh Syeikh Muhammad Tahir, atau Datu Negara. Di Margasari Islamisasi yang bercorak sufistik dilakukan oleh Syeikh Yusuf Khair. ${ }^{3}$ Dalam tradisi lisan masyarakat Banjar, ada tokoh sufi yang dikenal bernama Abdul Hamid Abulung. Ia adalah tokoh sufi yang senasib dengan al-Hallaj yang dieksekusi mati karena paham panteistik yang dianutnya. Versi populer ia dieksekusi mati oleh kerajaan berdasarkan fatwa yang dikeluarkan oleh Syeikh Arsyad al-Banjari yang dianggap sesat dan menyesatkan. Menurut Asywadi Syukur yang dikutip oleh Mujiburrahman menyatakan bahwa pernyataan ini tercermin dari fatwa yang dikeluarkan Arsyad al-Banjari yang tertulis dalam kitab Tuhfat al-Raghibin, "tiada syak pada wajib membunuh dia karena murtadnya. Dan membunuh seumpama orang itu terlebih baik daripada membunuh seratus kafir yang sah”. Menurut Steenbrink cerita Abulung ini merupakan cerita al-Hallaj versi Banjar, sedangkan cerita al-Hallaj versi Jawanya adalah cerita Syeikh Siti Jenar. Kesimpulan Steenbrink bisa jadi benar dan bisa juga kurang tepat. Sebab selama ini cerita Abulung adalah kisah yang turun temurun yang dikisahkan secara lisan. ${ }^{4}$ Walaupun demikian, disebuah desa di kawasan desa Sungai Batang Martapura Barat terdapat makamnya. Terlepas dari perdebatan keberadaannya, Syeikh Arsyad memang tidak sependapat dengan paham tasawuf semacam itu.

Muhajirin dalam penelitiannya bahwa ketidakpesatan kajian hadis para ulama Nusantara tersebut tidak bisa dilepaskan dari faktor historisnya, ia menyebutkan secara historis memang Islam Indonesia pada mulanya menganut paham bersifat sufistik. Sehingga tidak mengherankan jika pada masa awal-awal Islam di Nusantara banyak dijumpai literatur-literatur sufistik yang beredar di masyarakat lokal. Begitupula dengan materi fikih yang senantiasa disajikan kepada masyarakat lokal yang berujung kepada taqlid dengan empat imam besar, terutama al-Shafi'i. Kajian tasawuf dan fikih pada masa awal Islam Nusantara ini terus berkembang dan diajarkan kepada generasi penerusnya, imbasnya ungkap adalah kedua ajaran tersebut berkembang menjadi sebuah doktrin yang terpatri tanpa harus dikaji dan diolah kembali. ${ }^{5}$

\footnotetext{
${ }^{3}$ Yusliani Noor, "Sejarah Perkembangan Islam di Banjarmasin dan Peran Kesultanan Banjar (Abad XV-XIX)”, Jurnal al-Banjari, Vol.11. No. 2. (2012), h. 239-253.

${ }^{4}$ Mujiburrahman, "Tasawuf di Masyarakat Banjar: Kesinambungan dan Perubahan Tradisi Keagamaan”, Jurnal Kanz Philosophia, Vol. 3, No.2 (Desember 2013), h. 155-158.

${ }^{5}$ Muhajirin, Transmisi Hadis di Nusantara: Peran Ulama Hadis Muhammad Mahfudz alTarmasi, Disertasi SPs UIN Jakarta, 2009, h. 1-3.
} 
Millatī, Journal of Islamic Studies and Humanities, Vol. 2, No. 2, Des. 2017: 169-194

Kajian Hadis pada masa awal Islam di Nusatara menyatu dengan kajiankajian tasawuf, fikih, dan tauhid. Kadang hadis hanya menjadi sebuah legitimasi paham-paham keagamaan yang ditawarkan oleh ulama Nusantara. Kajian-kajian semisal sharh hadis, kritis terhadap kualitas hadis yang ditulis secara mandiri belum ada, yang ada hadis hanya masuk dalam pembahasan keilmuan lainnya dalam Islam.

Secara keilmuan, karya-karya ulama Nusantara pada kajian tasawuf sangat dominan. Fauzi Deraman menyatakan bahwa pada abad ke XVII adalah masa keemasan dibidang tasawuf ini. Tradisi intelektual keislaman oleh Jama'at alJawiyin yang dituangkan dalam karya-karya mereka tentunya memuat beberapa hadis. Posisi hadis dalam karya mereka menempati ragam posisi, bisa menjadi penjelas, penguat argumen, atau bahkan membantah tradisi budaya yang bertentangan dengan Islam. ${ }^{6}$ Fenomena perpaduan kajian tasawuf dengan syariah yang berlandaskan al-Qur'an dan menjadikan hadis-hadis sebagai sumbernya disebut dengan istilah neo-sufisme, paham ini bukanlah paham yang baru dalma kajian Islam, al-Ghazali (w. $1111 \mathrm{M}$ ) adalah pelopor model kajian ini yang dituangkan dalam beberapa karyanya, salah satunya adalah Ihya 'Ulum al-Din.

Kecendrungan paham neo-sufisme inilah yang membuat proses penyebaran hadis di Nusantara secara tidak langsung ikut tersebar juga melalui proses ini. Asumsi ini diperkuat dengan temuan Khader dalam risetnya yang menemukan bahwa kitab tasawuf karya 'Abd al-S\}amad al-Falimbani dengan judul Hidayat al-Salikin memuat 176 hadis. Secara afiliasi mazhab, kitab ini merupakan kiblat dari paham yang dikembangkan oleh al-Ghazali. Dari data hadis tersebut, secara kualiatas ia menjelaskan terdapat 57 hadis yang Shahih, 10 hadis hasan, 60 hadis da' if, 3 hadis mawdlu', 22 hadis mukhtalaf, dan sebanyak 24 hadis yang tidak ditemukan sumbernya. ${ }^{7}$ Riset Khader ini disatu sisi mengungkap status hadis yang ada dalam kitab tasawuf ulama Nusantara, namun disatu sisi juga memberikan argumen bahwa semua karya kitab tasawuf ulama Nusantara itu pasti mengutip beberapa hadis, kendati status hadisnya masih dipertanyakan.

Kalimantan Selatan sebagai salah satu provinsi yang entitas kemuslimannya terbesar di Indonesia sebanarnya sangat kaya akan pemikiran dan produk karyakarya dari ulama terdahulu. Namun 'warisan intelektual' itu masih berserakan

${ }^{6}$ Fauzi Deraman, "Karya-karya 'Ulum al-Hadith di Nusantara: Satu Sorotan”, Journal of al-Qur'an E⿱ Hadith Al-Bayan, Vol. 8, No. 10, (2010), h. 128-129.

${ }^{7}$ Khader Ahmad, "Autoriti Hadith dalam Kitab Tasawuf Tulisan Jawi: Satu Kajian Terhadap Kitab Hidayah al-Salikin”, h. 114-117. 
dan masih belum ada peneliti yang berminat melakukan kajian serius. Seringkali penelitian yang dilakukan di Kalimantan Selatan hanya berkisar pada asal-usul (sejarah) wilayah, potensi alam dan pergerakan politiknya.

Setidaknya ada dua penelitian yang bisa dikatakan fokus mengkaji peninggalam warisan intelektual ulama al-Banjari dalam kajian hadis. Pertama penelitian yang dilakukan oleh Rahmadi \& Husaini Abbas yang berjudul Islam Banjar: Genealogi dan Referensi Intelektual dalam Lintasan Sejarah. Penelitian ini hanya menyebutkan beberapa ulama al-Banjari yang meninggalkan warisan karya tulis dibidang hadis. Namun penelitian ini kemudian sangat memberikan kontribusi bagi penelitian selanjutnya yang dilakukan oleh Saifuddin, Dzikri Nirwana, dan Bashori yang menganalisis konten dari karya-karya ulama alBanjari. Adapun penelitian yang dilakukan ini berangkat dari persoalan yang belum tuntas terjawab dari kedua penelitian tersebut. Fokus permasalahan dalam penelitian adalah bagaimana pola jaringan hadis ulama al-Banjari selama ini, kemudian seberapa jauh pengaruh genealogi intelektual itu mempengaruhi pandangan ulama al-Banjari dalam kajian hadis yang terdapat dalam naskahnaskah yang mereka tulis.

\section{Timur Tengah: Destinasi Keilmuan ulama al-Banjari}

Jaringan Timur Tengah tetap menunjukkan kontribusinya bagi pengembangan intelektual Islam. Penyebutan istilah Jaringan Timur Tengah lebih cocok, ketimbang dengan istilah Jaringan Haramayn yang fokus di Mekkah dan Madinah saja. Sebab dari pembacaan terhadap 'journey for seeking knowledge' ulama alBanjari, mereka tidak saja berada di Mekkah dan Madinah, tapi juga ke Mesir.

Mekkah dan Madinah atau yang lebih dikenal dengan 'tanah haram' memainkan peranan yang sangat penting dalam Islam. Mekkah mempunyai ka'bah tempat orang shalat setiap saat, sedangkan di Madinah ada makan Nabi saw dan para Sahabat. Kondisi sosial politik di Haramayn pada kurun waktu abad ke-16 masehi yang semakin membaik, ditambah dengan 'fada'il' yang dimiliknya membuat orang-orang semakin tertarik untuk migrasi ke Haramayn. Banyaknya imigran yang berdatangan ini sebenarnya beragam motifnya. John O. Voll sebagaimana yang dikutip Azyumardi Azra menjelaskan setidaknya ada tiga motif banyaknya imigran berdatangan; 1) orang-orang yang awalnya pergi untuk berhaji, kemudian dengan berbagai alasan merasa nyaman tinggal disana dan menetap; 2) para ulama dari berbagai daerah Islam yang menetap kesana untuk ikut dalam wacana keilmuan; 3) para pelajar dari berbagai belahan dunia 
Millatī, Journal of Islamic Studies and Humanities, Vol. 2, No. 2, Des. 2017: 169-194

yang ingin menuntut ilmu dengan para ulama di Haramayn. ${ }^{8}$

Dari hasil pembacaan terhadap beberapa catatan tentang biografi ulama-ulama la-Banjari, generasi-generasi yang belajar di Timur Tengah dapat diklasifikasikan menjadi tiga generasi; 1) generasi pertama; atau disebut pula dengan fase pembuntukan jaringan; 2) generasi kedua; fase penguatan jaringan; 3) generasi ketiga; fase pelestarian jaringan.

Generasi pertama pada masa abad ke-19 M. ini merupakan generasi awal yang membangun dan memperkenalkan kepada masyarakat internasional di Haramayn tentang daerah Banjar, yang kemudian disebut dengan al-Banjari. Ia adalah Arsyad al-Banjari yang disebut sebagai orang banjar pertama yang membangun tradisi intelektual belajar di Haramayn. Gelar atau dalam istilah kaidah bahasa Arab disebut 'laqab' kedaerahan sebenarnya menjadi identitas bagi pelajar di Haramayn dalam pola interaksi sesama murid, atau interkasi sesama guru. Etnis Nusantara di Haramayn dikenal dengan sebutan kedaerahannya itu jumlahnya tergolong banyak, yang berasal dari Aceh (al-Sinkili, al-Ashi), Minangkabau (al-Minangkabawi, al-Fadani), Mandailing (Mandili), Melayu Sumatera Selatan (al-Palimbani), Jakarta (al-Betawi), Sunda (al-Bantani, alGaruti), Jawa (al-Turmusi, al-Kadiri, al-Banyumasi), Sambas (al-Sambasi), Bugle (al-Maqassari), Semenanjung Melayu (al-Kalantani), Patani (al-Patani), Bima dan Sumbawa (al-Sumbawa) dan daerah Banjar (al-Banjari).

Generasi kedua adalah yang dibangun oleh Syeikh Kasyuf Anwar dan Sya'rani Arif al-Banjari. ketika berada di Haramayn pada awal abad k-20 M. Mereka berdua belajar hadis kepada Syiekh 'Umar Hamdan (w. 1368 M). 'Umar Hamdan merupakan muhaddith yang dikenal banyak mempunyai sanad hadis yang superior atau 'uluw'. Ia sebagai pengajar di mesjid Nabawi pada tahun 1334 $\mathrm{H}$, pengajar di mesjid al-Haram pada tahun $1334 \mathrm{H}-1368 \mathrm{H}$, pengajar di madrasah al-Falah ada tahun 1352-1365 H, pengajar di Madrasah Saulatiyah pada tahun 1352-1365 H, dan selalu memberikan pengajaran di rumahnya sendiri, baik ketika di Makkah maupun Madinah (Ridlo, 71-78). Sya'rani Arif merupakan salah satu muridnya yang mendapatkan gelar 'khalifah' darinya. Gelar ini menunjukkan kapasitas keilmuan yang dimiliki, dan tentu saja ini membuat Sya'rani Arif mendapatkan tempat sebagai pengajar di Mesjid al-Haram.

Generasi ketiga pada akhir abad ke-20 M yang diwakili oleh Syuker Unus, Abdul Wahid, Ahmad Fahmi Zamzam, dan Nurdir Marbu. Keempat

${ }^{8}$ Azyumardi Azra, Jaringan Ulama Timur Tengah dan Kepulauan Nusantara Abad XVII Eु XVIII, 74-76. 
ulama ini masih tetap mengeksiskan keberadaan pelajar Banjar di Haramayn. Kendati mereka banyak juga belajar dibeberapa daerah, namun tampaknya Haramayn tetap pilihan utama sebagai destinasi keilmuan yang selalu dituju. Kendati tidak dalam waktu bersamaan, keempat ulama ini setidaknya pernah belajar dan mengambil ijazah kepada tiga ulama 'besar' di haramayn waktu itu. ketiga ulama itu adalah Syeikh Yasin al-Fadani, Syeikh Sayyid 'Alwi al-Maliki, dan Syeikh Isma'il Zayn al-Yamani.

Jaringan Timur Tengah sekali lagi membuktikan eksistensinya di Nusantara. Eksistensi itu bisa dilihat dari pertumbuhan intelektual, proses penyebaran Islam, pembaharuan ide-ide Islam di Nusantara tidak bisa dilepaskan dari pelajar yang belajar di Timur Tengah. Ide-ide pembaharuan keislaman yang sifatnya lebih lokalitas, membaca konteks, dan mengomodasi budaya lokal menjadi ciri khas jaringan Ulama Timur Tengah ini.

Salah satu buktinya adalah kitab-kitab kajian hadis yang menggunakan bahasa Arab Melayu, rekategorisasi penulisan kitab hadis yang tema-temanya menyesuaikan kondisi lingkungan. Setidaknya itulah salah satu dari sekain banyak yang terlihat dari peran yang dilakukan oleh ulama al-Banjari dalam transmisi hadis. Jumlah kitab yang menjadi mereka hasilkan sebanyak 31. Kitab hadis inilah yang menjadi sumber primer dalam penelitian ini. Hadis-hadis yang ada dalam kitab mereka tidak dikaji secara takhrij dengan menggunakan kaidah ilmu jarh wa ta'dil yang pada ujung kajian berkesimpulan bahwa suatu hadis itu lemah atau kuat. Namun takhrij dalam penelitian hanya akan sampai pada penyebutan sumber-sumber hadis tersebut, jika dalam kitab-kitab tersebut tidak disebutkan mukharrijnya. Kitab-kitab hadis karya ulama al-Banjari ini dikaji dari sudut pandang melihat distingsi kajian hadis mereka dari pola transmisinya, dan orisinalitas pemahaman hadisnya.

Jika ada yang meragukan dan mempertanyakan keorisinalitas dan tingkat keilmuan karya-karya ulama al-Banjari ini, maka hal ini bisa jadi sangat beralasan. Sebab ada kesan sekilas bahwa karya-karya tersebut banyak yang bersifat copius dari kitab-kitab standar hadis. Namun yang menjadi persoalan bukan pada keorisinalitasnya itu, tetapi lebih kepada pendekatan-pendekatan baru yang mereka lakukan guna lebih memahami kembali hadis-hadis Nabi saw.

Dengan demikian, wacana intelektual yang mereka kembangkan dalam masyarakat Banjar adalah wacana yang bertitik berat pada hadis-hadis. Hadishadis yang terkesan masih "besar" dan sulit dijangkau oleh masyarakat awam lebih disederhanakan bentuknya dengan cara penulisan ulang kembali hadis itu 
Millatī, Journal of Islamic Studies and Humanities, Vol. 2, No. 2, Des. 2017: 169-194

atau yang disebut dengan istilah rekategorisasi. Dengan proses perkenalan yang lebih mudah, ditambah dengan makin tersebarnya hadis-hadis tersebut semakin memperteguh signifikansi posisi ulama al-Banjari dalam proses pembaharuan Islam di Banjar.

\section{Generasi Pertama: Fase Pembentukan Jaringan Ulama “Timur Tengah-Banjar"}

Tradisi rihlat 'ilmiyyah ulama al-Banjari ke Haramayn mulai mengakar saat pertama kalinya Arsyad al-Banjari (w. 1812 M) diberikan beasiswa pendidikan oleh kerajaan Banjar yang dipimpin Sultan Tahlil Allah (w. 1745 M). Menurut Abu Daudi beasiswa yang diberikan tidak tanggung-tanggung, jumlahnya sangat besar. Semua keperluan selama studi disana semua terjamin. Rumah disediakan dikawasan Syamiah yang terkenal dengan nama Barhat Banjar. Belum ditemukan apa yang mendorong kesultanan Banjar pada masa itu untuk memberikan besiswa tersebut. ${ }^{9}$ Namun dapat dipastikan bahwa bantuan pendidikan kepada Arsyad al-Banjari merupakan langkah yang strategis dalam perkembangan Islam selanjutnya di masyarakat Banjar. Sebab menurut Azyumardi Azra kepatuhan masyarakat banjar terhadap Islam sangat minim dan tidak lebih dari pengucapan syahadah" saja. ${ }^{10}$ Bisa saja penyataan Azra ini benar dan bisa jadi kurang tepat. Bisa jadi benar sebab sebelum masa Syeikh Arsyad dakwah Islam masih kurang agresif. Ulama yang "masuk" dalam pemerintahan bisa dikatakan sedikit, yaitu Khatib Dayan (Syeikh Maulana Syarif Hidayatullah) yang merupakan utusan dari kerajaan Demak. ${ }^{11}$

Selama studi disana, Arsyad al-Banjari bertemu dan bersahabat dengan pelajar lainnya seperti Syeikh Abd al-Samad al-Palimbani, Abd al-Wahab Bugis, dan Abd al-Rahman Misry dari Betawi (Jakarta). Empat serangkai ini pun belajar tarekat Samaniyyah bersama-sama dengan 'Abd al-Karim al-Samman al-Madani. Sampai sekarang tarekat Sammaniyah sangat populer di masyarakat Banjar, dan dibeberapa daerah dilaksanakan pembacaan manakib al-Madani pada saat wafatnya pada bulan Dzulhijjah. Selain dengan al-Madani, Arsyad al-

${ }^{9}$ Abu Daudi, Maulana Syeikh Muhammad Arsyad al-Banjari (Tuan Haji Besar) (Martapura: Yayasan Islam dalam Pagar, 2003). KH. Irsyad Zein/ Abu Daudi merupakan keturunan dari Syeikh Arsyad yang wafat pada tanggal 18 Maret 2016. Lihat juga: Munawwar, Risalah al-Shamad (Martapura: tp, t.th). Khairil Anwar, “Ulama Indunisiyya al-Qarni al-Thamin 'Ashar: Tarjamah Muhammad Arshad al-Banjari wa Afkaruhu”, Jurnal Studia Islamika, Vol. 3. No. 4, (1996). 137-164.

${ }^{10}$ Azyumardi Azra, Jaringan Ulama Timur Tengah, h. 328.

${ }^{11}$ Rahmadi \& Husaini Abbas, Islam Banjar: Genealogi dan Referensi Intelektual dalam Lintasan Sejarah (Banjarmasin: IAIN Antasari Press, 2012), h. 9-10. 
Banjari mempunyai beberapa guru lainnya yang terkenal: 'Ata' Allah al-Misri, Muhammad Ibn Sulaiman al-Kurdi, Muhammad al-Jauhari, Ahmad ibn 'Abd Mum 'in al-Damanhuri, Ibrahim al-Ra' is.

Dalam karya tulisnya, tidak ada satupun karya tulis yang fokus membahas kajian hadis. Kendati demikian, bukan berarti bahwa ia tidak mempunyai kapasitas yang memadai di bidang hadis. Menurut catatan Shagir Abdullah, Arsyad al-Banjari mempunyai sanad hadis dari Salim ibn 'Abd Allah (w. 1160 H). ${ }^{12}$ Salim ibn 'Abd Allah adalah pakar hadis yang banyak mempelajari hadis-hadis dari berbagai macam kitab yang ia dapatkan dari ayahnya sendiri, 'Abd Allah al-Basri. ${ }^{13}$ al-Basri sendiri merupakan ulama yang mempunyai sanad hadis yang 'uluw (superior), dalam kitabnya al-Imdad bi Ma'rifah 'Uluw al-Isnad dijelaskan sumber-sumber hadis yang dipelajari, termasuk mengambil hadis dari jalur Ibn "Arabi, yang sering dituduh sebagai seorang sufi yang "menyimpang", namun ia merupakan sumber otoritas dalam sanad hadis.

Kendati kepakaran hadisnya tidak diekspresikan kedalam karya-karya yang fokus dalam kajian hadis, Arsyad al-Banjari dalam karya-karyanya, setidaknya ada dua karya yang dijadikan objek penelitian adalah sabil al-muhtadin dan Tuhfat al-Raghibin. Dalam Sabil al-Muhtadin menurut riset yang dilakukan oleh Khairil Anwar (2007) ditemukan sebanyak 223 hadis dengan keterangan 167 Shahih, 21 Hasan, 21 Dla'if, 1 Dla'if Jiddan, 7 Mauquf, 1 Maqtu', 5 belum diketahui. ${ }^{14}$ Jika diperhatikan, kualitas hadis-hadis yang terdapat dala kitab sabil al-muhtadin ini tidak semuanya otoritatif, ada 35 hadis yang statusnya termasuk hadis yang lemah. Temuan ini mengindakasikan bahwa sebagai produk kajian hukum, kitab tersebut belum mempunyai kekuatan 'dalil' yang otoritatif.

Hadis-hadis yang dikutip dalam kitab tersebut setidaknya mempunyai 4 fungsi; 1) sebagai sumber hukum utama dari sebuah ibadah; 2) sebagai dalil suatu hukum perbuatan yang diistinbat dari hadis tersebut; 3) sebagai dalil yang memberikan petunjuk teknis suatu ibadah; dan 4) sebagai dalil untuk fada'il al-A'mal (keutamaan beramal).

${ }^{12}$ Wan Mohd Shagir Abdullah, Syeikh Muhammad Arsyad al-Banjari Pengarang Sabil alMuhtadin (Kuala Lumpur: Khazanah Fathaniyah, 1990), h. 6-7.

13 'Abd Allah ibn Sa>lim al-Makki, al-Imdad fi Ma'rifat 'Uluw al-Hadith (Riyad: Dar al-Tauhid, t.th), h. 53-54.

${ }^{14}$ Abdul Majid, Telaah Kritis Terhadap Hadis-hadis Sabil al-Muhtadin, Tesis, (Jakarta: Sekolah Pascasarjana UIN Syarif Hidayatullah Jakarta, 2007), h. 171. Namun tampaknya data yang dikemukakan oleh Majid ini masih bisa direvisi, sebab Majid melupakan hadis-hadis yang ditulis dalam bahasa Melayu/ Arab Pegon. 
Millatī, Journal of Islamic Studies and Humanities, Vol. 2, No. 2, Des. 2017: 169-194

Sedangkan untuk kitab Tuhfat al-Raghibin ditemukan sebanyak 21 hadis. Adapun fungsi hadis-hadis tersebut mempunyai 3 fungsi yaitu; 1) sebagai dalil menguatkan pendapat tentang keimanan; 2) sebagai dalil menjelaskan tentang kekeliruan dalam beberapa firqah dalam Islam; 3) sebagai dalil untuk melakukan pembaharuan terhadap tradisi masyarakat lokal seperti menyanggar dan mambuang pasilih.

Temuan-temuan ini menunjukkan bahwa kecendrungan Arsyad al-Banjari dalam kajian hadis sangat terlihat dalam literatur karya-karyanya. Kecendrungan model seperti ini kuat dugaan bahwa hadis memainkan peranan penting dalam pembentukan model Islam di kawasan Kalimantan. Corak Islam yang terbentuk tidak jauh dari adanya perpaduan yang harmonis antara al-Qur'an, pemahaman hadis, aktifitas tarekat, dan syari'at. Dalam aktifitasnya sebagai dalam tarekat, Arsyad al-Banjari adalah murshid dari tarekat sammaniyyah, sedangkan dalam aktifitas syariah, karyanya sabil al-muhtadin menjadi jawaban bahwa perhatiannya terhadap hukum Islam sangat serius. Model seperti ini yang disebut oleh John O. Voll (2008) dengan istilah Neo-Sufisme. Istilah ini pada mulanya digunakan untuk menggambarkan perkembangan pembaharuan Islam pada akhir abad ke-18 dan awal abad ke-19.

\section{Generasi Kedua: Fase Pelestarian Jaringan}

Pada fase ini diwakili oleh dua ulama al-banjari yang masih mempunyai darah keturunan dari Arsyad al-Banjari, yaitu Kasyful Anwar al-Banjari (w. 1940 M) dan Muhammad Anang Sya'rani al-Banjari (w. 1969 M). Kasyful Anwar adalah sosok yang penting dalam perkembangan Islam di masyarakat Banjar, ia adalah pendiri dan sosok pembaharu dalam sistem pendidikan islam di Pondok Pesantren Darussalam Martapura.

Dari catatan yang ditemukan tentang perjalanan rihlat 'ilmiyyahnya Kasyful Anwar disebutkan bahwa pada tahun $1313 \mathrm{H}$ atas inisiatif kakeknya Muhammad Arsyad dan neneknya Hj. Aisyah, diberangkatkanlah ia ke Mekkah untuk menuntut ilmu. Dalam perjalanan tersebut, ayah dan ibu serta kakek dan neneknya ikut serta dalam perjalanan tersebut. Ayah dan ibunya wafat di Mekkah pada beliau menuntut ilmu. ${ }^{15}$ Dari fakta ini, tidak bisa dipungkiri bahwa peran keluarga dalam membentuk karakter, pribadi dan kapasitas intelektual sangat berpengaruh.

${ }^{15}$ Munawwar, Nur al-Absar fi Dhikri Nubdhah min Manaqib al-Syeikh Muhammad Kasyf al-Anwar (Martapura: Putra Sahara, t.th), 2-3. 
Ketika berada di Mekkah, ia belajar bahasa Arab dengan Muhammad Amin al-Banjari (buyut dari Arsyad al-Banjari) orang Martapura yang sudah lama menetap disana guna bisa berkomunikasi dan belajar. Tampaknya komunitas pelajar Banjar tetap bertahan dan terus bertambah jumlahnya pasca dibangun oleh Arsyad al-Banjari.

Selama di Mekkah ia banyak mendapat sanad hadis yang otoritatif dari gurunya 'Umar Hamdan, seoran musnid hadis terbesar dimasanya. Dalam catatan sanadnya, keilmuan 'Umar Hamdan terhubung dengan musnidah hadis wanita yang ada di Damaskus, al-Musnidah Zaynab bint al-Kamal (w. $670 \mathrm{H}$ ), dan sampai kepada Imam al-Bukhari. ${ }^{16}$ Menurut Riset yang dilakukan oleh Asma Sayeed tentang peranan perempuan dalam transmisi hadis, Zaynab merupakan transmitter yang sentral dalam perkembangan transmisi hadis di Damaskus. ${ }^{17}$

Selain itu dia belajar dengan beberapa guru lainnya semisal al-Sayyid Ahmad ibn Abu Bakr Shata (w. 1332 H) anak dari pengarang kitab I'anah alThalibin, al-Habib Ahmad ibn Hasan al-'Attas (w. 1332 H), al-Syeikh Muhammad 'Ali ibn Husayn al-Maliki (w. 1367 H).

Sekembalinya ke Tanah Air, Kasyful Anwar termasuk salah satu ulama al-Banjari yang produktif dalam menghasilkan karya tulis. Salah satu karyanya dibidang hadis adalah Penjelasan/komentar beliau terhadap kitab hadis-hadis dalam kitab Arba'in al-Nawawi yang diberi judul Tabyin al-Rawi bi Sharh Arba'in al-Nawawi yang ditulis dengan menggunakan bahasa Arab Melayu.

Salah satu bukti bahwa pengaruh ulama Timur Tengah dalam proses pembentukan pemahaman keislaman sangat berpengaruh bisa dijumpai dalam kitab sharh hadis ini. Dalam kitab hadis karyanya Tibyan al-Rawi (21-21) terdapat hadis Pada hadis kelima "man ahdatha fi amrina hadha minhu fahuwa raddun, (al-Bukhari). Menurut Kasyful Anwar, hukum yang dapat ditarik dari hadis ini adalah bahwa segala sesuatu perbuatan yang tidak ada diperbuat pada zaman Rasulullah saw, dan tidak ada kaidah umum dari al-Quran, hadis, dan ijma', maka perbuatan tersebut dikategorikan sebagai tindakan yang bidah dala lalah.

${ }^{16}$ Catatan sanad ini penulis dapatkan dari Tuan Guru H. Muhammad Syukeri Unus al-Banjari, lihat dalam: Muhammad Syukeri Unus al-Banjari, Ni'mat al-Juwad li Thalib al-Isnad li kutub al-Sittah (Martapura: Dar al-Shakirin, t. th), 7

${ }^{17}$ Zainab merupakan muhaddits perempuan yang hidup di Damaskus yang mempunyai sanad hadis yang begitu banyak, sehingga mendapatkan gelar al-musnidah. Lihat dalam: Asma Sayeed, "Women and Hadith Transmission Two Case Studies from Mamluk Damascus", Journal Studia Islamica No. 95 (2002), 72. Diakses dari http://www.jstor.org/stable/1596142 pada tanggal 11-6-2015. 
Millatī, Journal of Islamic Studies and Humanities, Vol. 2, No. 2, Des. 2017: 169-194

Seperti perbuatan salat tanpa bersuci. Adapun segala perbuatan yang tidak ada di zaman Nabi saw, akan tetapi perbuatan itu ditopang oleh dalil-dalil yang umum dari al-Qur'an dan hadis, maka perbuatan tersebut termasuk kategori bid'ah hasanah (baik). Seperti membangun tempat belajar, sekolah, menulis kitab-kitab. Kasyful Anwar berpegang dengan dalil al-Qur'an yang umum: wa ta'awanu 'ala al-birr wa al-taqwa (saling tolong menolonglah dalam hal kebaikan, Q.S. 5:2). Begitu pula dengan amaliyah membaca maulid Nabi saw, dan berdiri ketika bacaan maulid tersebut sampai pada kisah Nabi saw dilahirkan. Segala bentuk perbuatan ini dengan maksud menunjukkan kecintaan terhadap Nabi saw. Argumen ini diperkuat oleh hadis: la yu'minu ahadakum hatta akuna ahabba ilayh min waladihi wa walidihi wa al-nas ajma'in (al-Bukhari). Artinya: "tidak sempurna iman seseorang dari kamu, hingga ia lebih mencintaiku daripada anaknya, orang tuanya,dan sekalian manusia lainnya". ${ }^{18}$

Tipologi bidah yang ditawarkan oleh Kasyful Anwar ini tampaknya berpegang dengan kaidah yang diajukan oleh al-Shafi'i (al-Dimyati, 313) yang mengatakan: ${ }^{19}$

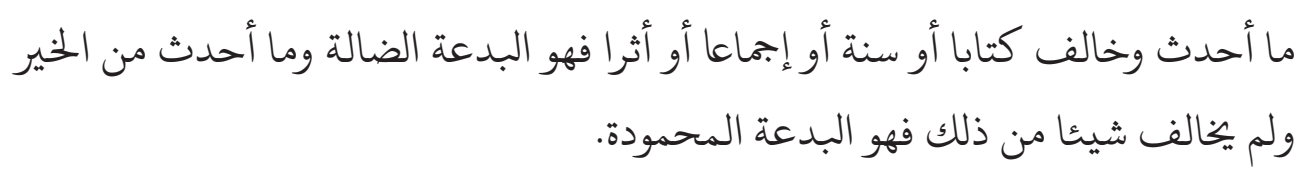

Artinya: Segala perbuatan yang bertentangan dengan al-Qur'an, hadis, ijma', dan athar maka termasuk dalam kategori bid'ah yang sesat, dan adapun segala perbuatan yang baik, tidak bertentangan dengan kaidah yang demikian itu, maka termasuk dalam kategori bid'ah yang baik.

Bidah menurut Kasyful Anwar adalah segala sesuatu tindakan yang tidak diperbuat oleh Rasulullah saw dan Sahabat. Definisi ini kiranya lebih luas dengan memasukkan perbuatan Sahabat sebagai acuan dalam bertindak, ketimbang dari definisi bidah umumnya yang hanya membatasi bidah dari segala perbuatan Rasulullah saja.

Tampaknya tipologi bidah yang ditawarkan oleh Kasyful Anwar ini sangat terpengaruh dengan gurunya al-Sayyid Ahmad ibn Abu Bakr Shata (w. 1332 H) anak dari pengarang kitab i'anah al-talibin. Sebab kutipan dari al-Shafi'i itu

${ }^{18}$ Muhammad Kasyful Anwar al-Banjari, al-Tabyin al-Rawi fi Sharh Arba'in al-Nawawi (Martapura: Dar al-Shakirin, t.th), 21-22.

${ }^{19}$ Abu Bakr ibn Muhammad Shata al-Dimyati, Hashiyat I'anah al-Thalibin (Beirut: Dar al-Fikr, t.th), 1/313. 
terdapat dalam kitab tersebut. Juga demikian dengan pendahulunya Arsyad alBanjari yang membagi bid'ah itu kepada dua, yang sesat dan yang baik.

Ulama al-Banjari yang kedua pada fase pelestarian jaringan ini adalah Muhammad Anang Sya'rani Arif, di makamnya tertulis dengan jelas gelar 'almufassir' dan 'al-muhaddith'. Gelar ini tidak lepas dari kapasitas keilmuannya dalam kedua bidang tersebut. Dilahirkan pada tahun 1914 di Kampung Melayu Martapura dan wafat pada tanggat 17 Juni 1969 dimakamkan di tempat yang sama. KH Muhammad Sya'rani 'Arif bin Fathuljannah binti Abdullah Khatib bin H. M. Shalih bin Khalifah H. Hasanuddin bin Syeikh Muhammad Arsyad al-Banjari. ${ }^{20}$

Pada tahun 1350/1930 M, Anang Sya'rani bersama sepupunya KH Syarwani Abdan Bangil berangkat ke Mekkah untuk melaksanakan ibadah haji, sekaligus menetap disana untuk belajar. Mainstream arah kiblat intelektual ulama al-Banjari lebih cendrung ke Mekkah dan Madinah. Tradisi ini terus berlanjut sampai generasi selanjutnya, dari Haramayn untuk Banjar. Di antara guru Anang Sya'rani adalah (1) al-Sayyid Muhammad Amin al-Kutbi (1303 H), (2) al-Syeikh 'Umar ibn Hamdan (w. 1368 H), (3) Syeikh 'Ali ibn 'Abd Allah al-Banjari.

Kepakarannya dalam bidang hadis bukan saja dilihat dari sanad hadis yang ia dapatkan, namun juga terlihat dair kapasitas keilmuannya yang mampu menghafal ribuan hadis lengkap dengan sanad dan matannya. Karya-karya dibidang hadis yang terpublikasi hanya ada dua, dan kedua karya tulis tersebut membahas tentang kajian hadis. (1) Tanwir al-Tullab fi Mustalah al-Hadith, kitab ini dicetak Pondok Pesantren Darussalam dengan jumlah 36 halaman. Karya ini selesai ditulis pada hari kamis 14 safar $1383 \mathrm{H}$. Tema yang dibahas adalah tentang ilmu hadis. Kitab ini bisa dikatakan hanya sebagai pengantar saja, sebab tidak ada pembahasan kritis tentang perdebatan ilmu hadis. Hal tersebut bisa dipahami, sebab kitab ini digunakan untuk pembelajaran santri-santri yang masih tingkat bawah. (2) Hidayat al-Zaman fi Ahadiht Akhir al-Zaman. Kitab ini dicetak oleh Pondok Pesantren Darussalam yang jumlah halamannya ada 27. Kitab ini merupakan rekategorisasi hadis, Sya' rani Arif menghimpun hadis-hadis tentang prediksi atau tanda-tanda akhir zaman atau kiamat. Sumber hadisnya pun beragam, jumlah hadis dalam kitab Bukhari dikutip ada 4 hadis, Muslim sebanyak 6 hadis, al-Tirmidhi 7 hadis, Abu Daud 1 hadis, al-Nasa'i 1 hadis, Ibn Majah 4 hadis, Imam Ahmad 4 hadis, al-Baihaqi 2 hadis, Abu Nu'ain 2 hadis, al-Darimi 1 hadis, ibn Abi Dunya 1 hadis, al-Khatib al-Bagdadi 1 hadis, Ibn

${ }^{20}$ Abu Daudi, Maulana Syeikh Muhammad Arsyad al-Banjari, 270. 
Millatī, Journal of Islamic Studies and Humanities, Vol. 2, No. 2, Des. 2017: 169-194

Mardawaih 1 hadis, al-Bazzar 1 hadis, al-Dailami 1 hadis, dan riwayat muttafaq 'alaih 1 hadis. Total hadis yang ada dikitab ini berjumlah 40 hadis. Adapun motif penulisan kitab ini dilandasi tujuan agar menjadi 'tadhkirah' atau pengingat bagi umat Islam tentang tanda-tanda hari kiamat. Agak disayangkan bahwa hadis ini tidak disertai dengan sharh (komentar), sehingga sangat sulit untuk melacak distingsi pemahaman hadisnya. Kendati begitu, pembuatan redaksi judul dalam setiap kutipan hadis bisa memberikan sedikit informasi tentang corak pemahaman hadisnya.

Adapun untuk corak kajian ilmu hadis, Sya'rani Arif dalam kitabnya Tanwir al-Tullab mendiskusikan sub-sub bahasan dengan metode dialogis atau tanya jawab dengan bahasa Arab. Tipologi dan diskripsi tentang kualitas hadis yang ia tulis hampir sama saja dengan karya dari pakar-pakar mainstream dalam kajian hadis. Dalam arus sejarah mustalah hadis, Sya'rani Arif mendiskusikan beberapa fase penting, mulai dari al-Shafi' ${ }^{\prime}$ (w.204) yang masih terintegrasi dengan kajian ushul fikih, kemudian ilmu ini berdiri secara mandiri ditandai dengan adanya karya dari al-Ramahurmuzi (w.364) dengan kitabnya al- alMuhaddith al-Fashil bayn al-Rawi wa al-Wa'i. Fase ketiga ditandai dengan adanya karya yang lebih komprehensif lagi pembahasannya, yaitu karya dari al-Hakim al-Naisaburi (w. 405) dengan kitabnya ma'rifat 'ulum al-hadith. Fase keempat pembahasan musthalah hadis lebih terperinci dan komprehensif dengan adanya karya dari al-Khatib al-Bagdadi (w. $463 \mathrm{H}$ ) yang berjudul al-kifayah. Pada fase kelima kajiannya sifatnya lebih melengkapi lagi dengan adanya karya dari ibn al-Salah (w.643). Pada fase keenam diskursus kajiannya lebih fokus kepada pembahasan yang ringkas, intisari dari pembahasan-pembahasan yang sudah matang pada fase-fase sebelumnya, salah satu kitab tipe seperti ini adalah Yahya ibn Sharaf al-Nawawi (w.642). Fase terakhir adalah kajian yang kontemporer sekarang ini. Menurut Saifuddin (2013) tipologi arus sejarah yang ditawarkan oleh Sya' rani Arif ini tergolong baru yang tidak akan ditemukan dalam tipologi yang ditawarkan oleh beberapa pakar semisal al-Nawawi, ibn Kathir. Selebihnya pembahasan yang disajikan dalam diskusi karya Sya'rani Arif lebih hampir sama saja dengan pembahasan-pembahasan mainstream pakar hadis lainnya.

Ia menetap di Mekkah selama 22 tahun. Sempat mengajar di Mesjid al-Haram. Pada tahun 1952 M, ia kembali ke tanah Banjar untuk meneruskan pengabdian terhadap ilmu dan agama. Pernah menjadi pimpinan Pondok Pesantren Darussalam pada tahun 1959 M- 1969 M. ${ }^{21}$

\footnotetext{
${ }^{21}$ Abu Daudi, Maulana Syeikh Muhammad Arsyad al-Banjari, 271.
} 


\section{Generasi Ketiga: Fase Pelestarian Jaringan}

Fase ini berlangsung pada tahun 1980-an sampai sekitar tahun 2000-an awal. Keempat ulama yang menjadi objek dalam penelitian ini, Syuker Unus, Abdul Wahid, Ahmad Fahmi Zamzam, dan Nurdir Marbu mempunyai guru hadis yang sangat otoritatif. Kendati berbeda 'angkatan' ketika belajarnya, keempatnya mempunyai guru yang sama, yaitu Isma'il 'Uthman Zayn al-Yamani (w. 1414 H), Muhammad Iwad al-Yamani, Yasin al-Fadani (w. 1990M), Hasan Muhammad al-Mashat (w. 1399 H).

Syukeri Unus merupakan ulama al-Banjari yang banyak memiliki sanad. Karya-karyanya sangat banyak, terhitung ada sebanyak 42 karya tulis yang telah dihasilkan yang meliputi: 14 karya tulis tentang manakib ulama-ulama terdahulu, 8 karya tulis dibidang tata bahasa, 1 karya tulis dibidang tauhid, 3 karya tulis tentang fikih, dan 2 karya tulis tentang kajian hadis. Kendati banyak, karyakaryanya hanya merupakan 'nuqilan' dari beberapa kitab besar. Kitab tata bahasa Arab yang ditulisnya dengan bahasa Arab melayu yang berjudul "Is'af al-Talibin" merupakan kitab yang sangat familiar di kalangan santri Banjar. Sajian dan pembahasan yang begitu mudah dengan metode 'Syahid' yang diperkenalkan oleh Tuan Guru Kasyful Anwar al-Banjari menjadikan kitab ini sebagai referensi awal bagi kalangan santri sebelum mengenal kitab kajian tata bahasa (nahwu) yang lebih tinggi bahasannya.

Dua karyanya dibidang hadis yang menjadi sumber dalam penelitian ini adalah; (1) Hadith al'Arba'in fi al'-ilm, kitab yang dicetak majelis taklim Dar al-Shakirin ini jumlah halamannya 48 halaman yang berisi 40 hadis tentang ilmu, dan ditambah dengan aneka doa diakhir pembahasan, dan beberapa sanad ijazah musalsal. Kitab ini selesai ditulis beliau pada tahun $1405 \mathrm{H}$. Sumber hadis dalam kitab ini pun beragam, 11 hadis dari riwayat al-Bukhari, 6 hadis riwayat Muslim, 20 hadis riwayat al-Tirmidhi, 8 hadis riwayat ibn Majah, 5 hadis riwayat Abu Dawud, 3 hadis riwayat Imam Razain, 2 hadis riwayat Imam al-Dailami, dan 1 hadis masing-masing dari riwayat Imam al-Tabrani, Imam Ahmad, Imam al-Darimi, al-Khatib, ibn 'Abd al-Bar, Abu Nua'im. (2) Dalil al-Thalibin fi Ma'rifat Asma al-Hadith, kitab ini merupakan kajian ilmu hadis yang diterbitkan pada tahun 1985. Bentuk pembahasan dalam kitab ini berupa "tanya-jawab" yang argumen jawabannya tersebut diperkuat oleh syair-syair "al-Manzumat alBayquniyyah” karya Imam al-Baiquni (w. 1080 H). Sehingga bisa dikatakan kitab hadis ini merupakan penjelasan singkat tingkat matan-matan tersebut. Dalam pembahasan terakhirnya, pengaruh ulama Timur Tengah sangat kental sekali, 
Millatī, Journal of Islamic Studies and Humanities, Vol. 2, No. 2, Des. 2017: 169-194

yaitu cara membaca hadis yang dipelajari dari Yasin al-Fadani. Awal kalimat yang diucapkan awal dalam pembacaan hadis, adalah:

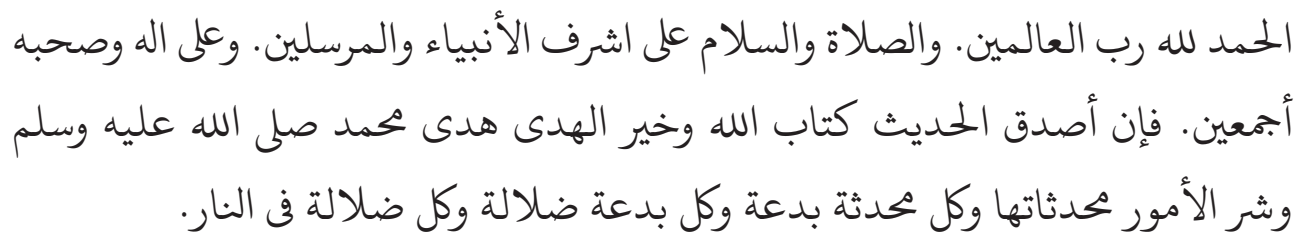

Muqaddimah ini terasa sangat penting dalam pembelajaran hadis di halaqoh ulama al-Banjari. Redaksi tersebut ditambah lagi dengan ungkapan: "wa bisanadihi al-muttasjil ila al-imam", yang menunjukkan bahwa orang yang membaca hadis tersebut mempunyai sanad yang terhubung dengan mukharrij hadis. Ini secara tidak langsung menegaskan bahwa sanad adalah bagian terpenting dalam mempelajari hadis, terlebih lagi ketika ingin menyebarkan hadis.

Berbeda dari Syukeri Unus, Abdul Wahid yang juga mempunyai guru yang sama lebih fokus dalam 'memberantas' hadis-hadis lemah yang sudah terlanjur beredar dan terpatri menjadi sebuah doktrin di tanah Banjar. Melalui karyanya yang berjudul Tadhkirah al-Lisan min al-Ahadith al-Mawdlu'at. Sebagaimana yang dibahas dalam diskusi di atas bahwa fokus kitab ini tertuju kepada hadis-hadis yang bermasalah secara kualitas menurut kajian Abdul Wahid al-Banjari. Metode yang digunakan dalam menilai validitas sebuah hadis adalah dengan cara meminjam penilaian ulama sebelumnya. Dalam beberapa tempat, Abdul Wahid secara tegas menulis bahwa nilai lemah suatu hadis yang ia teliti dilihat dari penilaian ulama sebelumnya. Misalnya ia menulis bahwa dalam kitab risalah al'usfuriyyah yang memuat 40 hadis, semua hadis dalam kitab ini termasuk dalam kategori yang palsu, hanya tiga hadis yang secara kualitas dapat dipertanggungjawabkan, atau dengan kata lain sahih. Begitu juga dengan menilai kitab tanbih al-ghafilin karya Abu al-Laith al-Samarqandi yang Abdul Wahid sebut dengan istilah 'fihi mawdlu'at kathirat'. Namun penilain ini agak kurang ilmiah, sebab Abdul Wahid hanya mengutip pendapatnya al-Dhahabi, tidak ada ekplorasi yang lebih kritis. Jika melihat metode yang dilakukan oleh Abdul Wahid dalam menentukan hadis-hadis yang bermasalah hanya dengan cara mengutip pendapat ulama terdahulu, hal ini sangat berbeda dengan yang dilakukan oleh Nashir al-Din al-Albani. al-Albani dalam menilai sebuah hadis dengan cara yang orisinil, dia membuka kembali kualitas para perawi dalam hadis, kemudian mengkaji ulang kembali beberapa redaksi teks dari matan 
hadis. $^{22}$ al-Albani menggunakan ijtihad intelektual yang gigih, hal ini sangat berbeda dari yang dilakukan oleh Abdul Wahid yang hanya 'menukil' pendapat ulama-ulama terdahulu, tanpa didasari metodologi yang kuat.

Secara metodologi memang penilaian Abdul Wahid terhadap beberapa hadis patut dipertanyakan. Kendati demikian, secara metode penulisan ia patut mendapatkan apresiasi. Kajian gigihnya dalam mengumpulkan beberapa hadishadis yang bermasalah dalam satu kitab menjadi nilai plus tersendiri. Sebab kitab ini bisa menjadi kitab praktis kegunaanya dalam menentukan hadis-hadis yang bermasalah.

Implikasi dari sikap tegas yang diperlihatkan oleh Abdul Wahid ini menggiring dia kepada sikap yang lebih skriptualis. Tradisi-tradisi keagamaan yang sudah lama mengakar yang berlandaskan hadis-hadis yang lemah dalam hal 'fadla'il al-a'mal' secara tegas ditentangnya.

Salah satu tradisi yang ditentangnya adalah perayaan malam nisf sha'ban, secara tegas ia berpandangan:

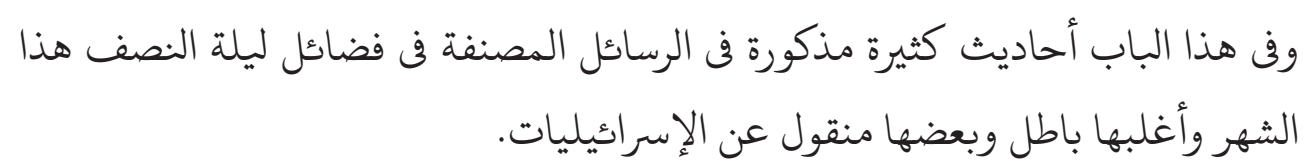

"Dalam pembahasan ini banyak sekali hadis-hadis yang disebut di beberapa kitab pada menyatakan kelebihan-kelebihan malam nisf al-Sha'ban, padalah moyaritasnya riwayatnya adalah batal, dan sebagiannya dikutip dari riwayat isra 'iliyyat".

Bagi sebagian masyarakat Banjar, tradisi beribadah pada malam nisf alsha'ban menjadi sebuah agenda dan rutinitas yang tidak bisa dilewatkan. Menurut Alfani Daud bulan sha'ban adalah bulan kedelapan dari penanggalan Arab, biasa dinamakan orang-orang Banjar dengan bulan nisfu. Pelaksanaan nisf al-sha'ban ini tepat dilaksanakan pada tanggal 15 sha'ban. Kegiatan ini diikuti oleh lakilaki dan perempuan, anak-anak yang sudah agak besar pun diikutsertakan pula. Kegiatan ini diawali dengan pelaksanaan shalat magrib berjamaah di mesjid atau di langgar yang kemudian diteruskan dengan pembacaan surah yasin bersamasama sebanyak tiga kali secara berturut-turut. Setiap kali membaca, tokoh yang

${ }^{22}$ Kamaruddin Amin, "Nasiruddīn al-Albānī on Muslim's Shahih: A Critical Study of His Method” Journal Islamic Law and Society, Vol. 11, No. 2 (2004), 149-170. http://www.jstor. org/stable/3399302, diakses pada tanggal 10-6-2015. 
Millatī, Journal of Islamic Studies and Humanities, Vol. 2, No. 2, Des. 2017: 169-194

memimpin acara memperingatkan tiga niat membaca yasin, yang pertama dengan niat mohon panjangkan umur dalam keadaan taat, yang kedua dengan niat memohon rezeki yang banyak dan halal, dan niat yang ketiga adalah memohon ditetapkan iman sampai akhir hayat. Setelah selesai membaca yasin tiga kali dilanjutkan dengan pembacaan doa khusus yang isinya menegaskan niat-niat tersebut. Setelah shalat Isya, amaliyah dimesjid atau dilanggar dilanjutkan lagi acara shalat tasbih secara berjamaah. Dan pada siang harinya masyarakat banjar melaksanakan puasa nisfu sya'ban. ${ }^{23}$

Tradisi yang digambarkan oleh Daud ini masih bertahan sampai sekarang, namun bagi Abdul Wahid tradisi semacam ini adalah tradisi yang berlandaskan hadis-hadis yang bermasalah. Salah satu hadis \yang dijadikan landasan bagi masyarakat Banjar tersebut:

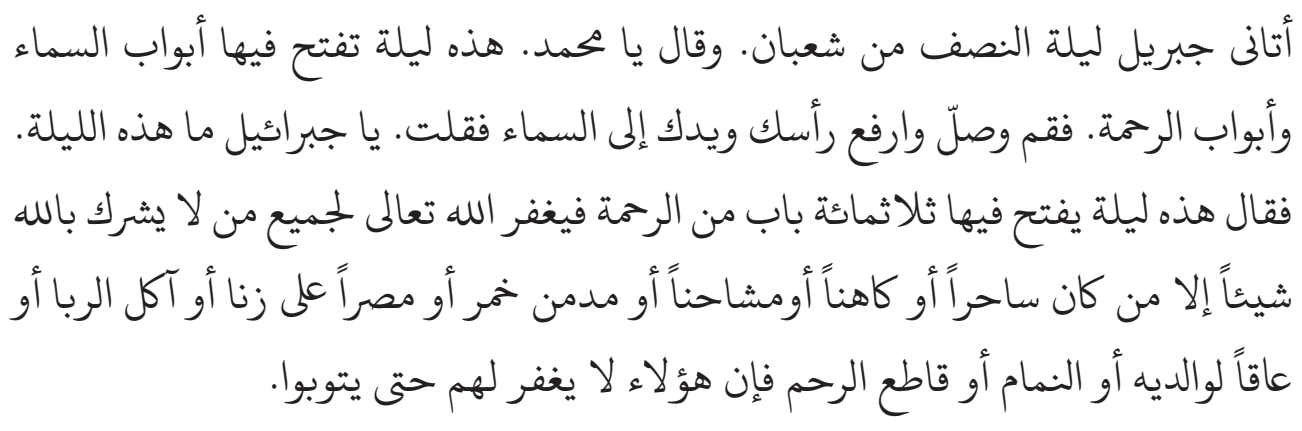

Jibril telah datang kepadaku dan mengatakan : 'Malam ini merupakan malam nisfu sya'ban, di dalamnya Allah membebaskan manusia dari neraka sebanyak bulu domba bani Kalb. Allah tidak melihat pada malam itu kepada orang musyrik, tidak pula kepada orang yang suka memusuhi, pemutus hubungan silaturrahim, orang yang musbil (memanjangkan pakaian melebihi mata kaki), orang yang durhaka kepada kedua orang tua, serta tidak pula kepada pecandu khamr (minuman keras)".

Secara tegas menurut Abdul Wahid, hadis ini statusnya lemah. Ia mengutip hadis ini dalam kitabnya al-mawdu'atnya al-Suyuti. Jika selama ini ulama al-Banjari hanya sebatas rekategorisasi hadis, namun langkah yang diambil oleh Abdul Wahid ini sangat terkesan anti mainstream. Dia menggugat tradisi Islam lokal yang sudah mengakar, sebab menurutnya tradisi semacam itu tidak berlandaskan kepada hadis-hadis yang dapat dipertanggungjawabkan.

${ }^{23}$ Alfani Daud, Islam dan Masyarakat Banjar: Diskripsi dan Analisa Kebudayaan Banjar (Jakarta: PT RajaGrapindo Persada, 1997), 334-336 
Dalam penggunaan hadis-hadis lemah yang dijadikan sebagai motivasi beramal, ulama al-Banjari memang terbagi menjadi dua. Pihak anti-mainstream yang menolak diwakili oleh Abdul Wahid, sedangkan pihak yang menerima diwakili oleh Arsyad al-Banjari dan Kasyful Anwar.

Pengaruh pemikiran ulama Timur Tengah lainnya yang begitu kental adalah adanya pengkajian hadis melalui metode musalsal. Hadis musalsal adalah proses periwayatan yang menuntut adanya proses kesamaan. Kesamaan itu baik dari segi perawi, dan segi periwayatan. Kesamaan itu pula bisa terjadi dalam bentuk perkataan, perbuatan, atau penggabungan antara perkataan dan perbuatan. ${ }^{24}$

Hadis musalsal yang sering diriwayatkan oleh ulama al-Banjari hanya terbatas pada kategori periwayatan musalsal dengan perkataan dan perbuatan, atau hanya dalam kondisi periwayatannya saja, bukan pada perawi. Penting dicatat, bahwa kategori hadis musalsal dalam diskursus keilmuan hadis sebenarnya terbagi kepada dua, diperawi dan diperiwatan. Contoh musalsal pada perawi misalnya adalah musalsal (sama) perawinya itu bernama muhammad dari awal hingga akhir (muh\}ammadin), atau perawinya sama pada huruf pertamanya yang dimulai dengan huruf ain, seperti riwayat 'Ali an 'Abd Allah an 'Umar. Sedangkan proses musalsal (adanya bentuk kesamaan) pada proses periwayatan itu seperti pada perbuatan, dan perkataan (al-San'ani: 2008: 412). Pola semacam inilah yang terjadi di masyarakat Banjar yang dibawa dan disebar oleh ulama al-Banjari. Ulama al-Banjari yang terlibat aktif dalam proses transmisi lewat hadis musalsal ini setidaknya ada tiga orang yaitu; 1) Syukeri Unus; 2) Fahmi Zamzam dan; 3) Nurdin Marbu.

Dari data yang penulis dapatkan, Syukeri Unus dalam karyanya Hadith Arba'in fi al'Ilm memberikan 2 buah hadis musalsal, pertama musalsal bi khatm al-majlis bi al-du'a (doa sesudah selesai majlis) yang termasuk dalam perkataan. Dalam skema sanad musalsal ini, Syukeri Unus dapat riwayat ini dan beri ijazah oleh Yasin al-Fadani melalui jalur Imam Malik ibn Anas dari riwayat 'Aisyah yang mengatakan apabila Rasulullah saw selesai dari majelis ilmu, maka ia menutupnya dengan doa:

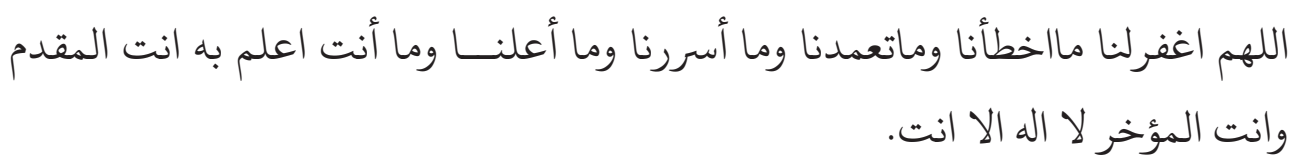

${ }^{24}$ Nur al-Din 'Itr, Manhaj al-Naqd fi 'Ulum al-Hadith, (Suriah, Dar al-Fikr, 1997), 354. 
Millatī, Journal of Islamic Studies and Humanities, Vol. 2, No. 2, Des. 2017: 169-194

Hadis musalsal kedua yang ditulis oleh Syukeri Unus adalah hadis al-rahmat al-musalsal bi al-awwaliyyah (perintah agar berkasih sayang). Dalam riwayatnya, Syukeri Unus mendapatkan ijazah hadis ini dari al-Fadani pada tanggal 25 Dzu al-Hijjah, hari rabu di Mekkah, tepatnya di rumah al-Fadani. Hadis ini diriwayatkan dari sahabat 'Abd Allah ibn 'Amr ibn al-'As yang diperintah oleh Nabi saw agar selalu berkasih sayang. Redaksi matan hadisnya adalah:

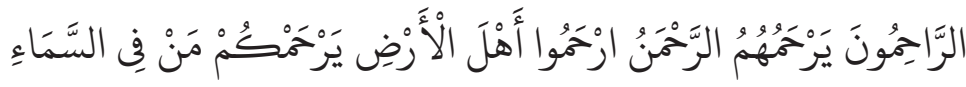

Orang-orang yg mengasihi akan dikasihi oleh al-Rah\{man (Allah), berkasih sayanglah kepada siapapun yg ada dibumi, niscaya Yang ada di langit akan mengasihi kalian.

Ulama al-Banjari selanjutnya yang menghidupkan tradisi hadis musalsal adalah Fahmi Zamzam. Dalam kitabnya, setidaknya ada tiga hadis musalsal yang ditransmisikan ke masyarakat Banjar. Pertama adalah hadis musalsal bi al-mahabbah (pengakuan cinta dari seorang rawi yang pengakuannya tersebut terhubung kepada Rasulullah saw). Dalam riwayatnya tersebut, Fahmi Zamzam mendapatkan sanad ini melalui dua orang gurunya, Sayyid 'Alwi al-Maliki dan al-Fadani. Kedua ulama besar Mekkah ini sama-sama mengambil sanad dari Syiekh 'Umar Hamdan al-Mahrusi yang terhubung melalui sahabat Mu'adh ibn Jabal yang mendapatkan pengakuan cinta dari Rasulullah saw jika tidak meninggalkan membaca doa (dibawah ini) setiap selesai salat:

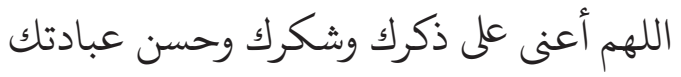

"Ya Allah berikah pertolongan-Mu kepadaku supaya aku senantiasa dapat berzikir akan Engkau dan bersyukur kepada Engkau dan dapat melaksanakan ibadah dengan sebaik-baiknya"

Kedua adalah hadis musalsal bi al-munawalah al-subhah (hadis musalsal tentang tasbih). Sama seperti riwayat di atas, Fahmi Zamzam juga mendapatkannya dari al-Fadani dan Sayyid 'Alwi al-Maliki yang terhubung kepada ahli tasawuf al-Sirriy al-Saqat\}iy dan sampai riwayat terakhir dari Hasan al-Basri (w. $728 \mathrm{M}$ ). Dalam riwayat itu terdapat percakapan antara al-Basri dengan muridnya yang bernama 'Umar al-Makki: "wahai guruku, kau mempunyai pangkat yang tinggi dan ibadah yang sangat baik, apakai kau sekarang masih memakai tasbih? AlBasri menjawab seraya mengatakan: 


$$
\text { هذا شىء كنا استعملناه فى البدايات ما كنا نتركه في النهايات }
$$

"Tasbih ini telah kami pakai sejak dari permulaan perjalanan kami menuju Allah swt, maka kami tidak akan meninggalkannya walaupun kami sudah sampai penghujung jalan"

Dari skema sanad ini, dapat dipastikan bahwa hadis musalsal ini tidak terhubung kepada Rasulullah saw, tetapi sampai pada periwayatan tabi' in saja, atau yang dala istilah 'ulum al-hadith disebut dengan istilah maqtu'. Seperti yang disepakati oleh mainstream ahli hadis, bahwa hadis maqtu' tidak bisa dijadikan landasan untuk hukum. Tampaknya penggunaan tasbih yang dimaksud dalam riwayat ini adalah untuk memudahkan seseorang berdzikir. Kemungkinan kedua adalah bahwa tasbih merupakan media yang sangat akrab dalam dunia sufistik. Sebab dari pembacaan biografinya, Fahmi Zamzam adalah seorang murshid tarekat Shadhiliyyat yang banyak sekali aneka ragam dzikirnya. ${ }^{25}$ Riwayat penggunaan tasbih dalam berdzikir ini sebenarnya ditopang oleh beberapa hadis dari Rasulullah saw, sehingga penggunaan tasbih sebagai media untuk beribadah yang diriwayatkan dari al-Basri ini didukung oleh sumber hadis yang lebih valid (Ahmad ibn Hanbal):

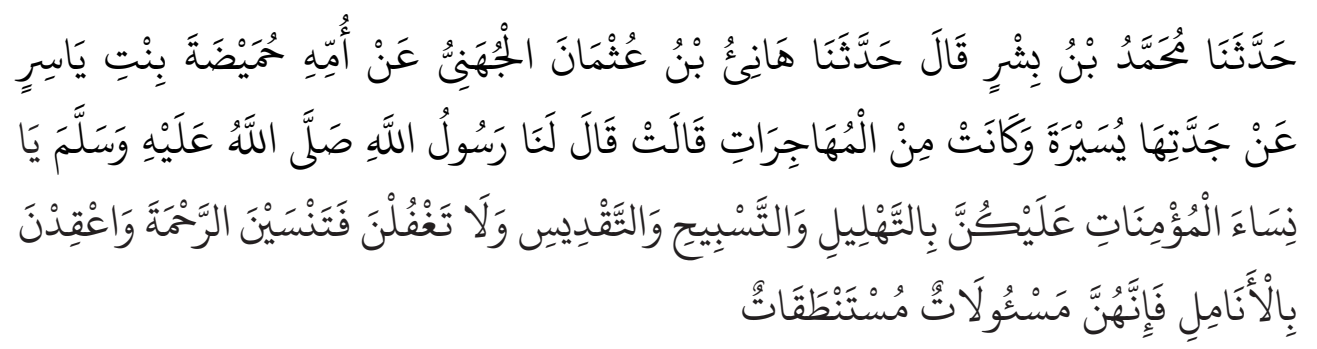

"Hai wanita muslimah, hendaklah kamu senantiasa bertasbih, bertahlil, dan ,mensucikan Allah, dan hitunglah yang demikian itu dengan jari-jari kamu karena jari tersebut akan ditanya pada hati kiamat dan ia disuruh berbicara"

Riwayat hadis musalsal yang ketiga dari Fahmi Zamzam adalah hadis musalsal bi al-musafahat (hadis berjabat tangan). Dalam riwayatnya, Fahmi Zamzam mempunyai dua jalur periwayatan, yaitu dari sahabat Anas ibn Malik dan dari abu al-'Abbas al-Mu'ammar. Dari riwayat Anas ibn Malik didapatkan 2015), 10 .

${ }^{25}$ Ahmad Fahmi Zamzam, 3 Hadis Musalsal (Banjarbaru: Pondok Pesantren Yasin, 
Millatī, Journal of Islamic Studies and Humanities, Vol. 2, No. 2, Des. 2017: 169-194

dari gurunya yang bernama al-Fadani dan Sayyid 'Alwi al-Maliki yang tersambung dengan riwayat sahabat Anas ibn Malik. Fahmi Zamzam menyadari bahwa hadis ini secara kualitas rawi sangat lemah dan tergolong dalam kategori hadis dla'if (lemah). Ia mengikuti pendapatnya al-Sakhawi yang mengatakan bahwa salah satu perawinya yang bernama Abu Hurmuz adalah seorang perawi yang pendusta. Tetapi secara redaksi matannya, hadis ini termasuk dalam kategori sahih, hal ini karena banyaknya riwayat lain yang meriwayatkan hadis yang sama, dan terhubung dengan riwayat sahabat Anas ibn Malik (Ahmad ibn Hanbal):

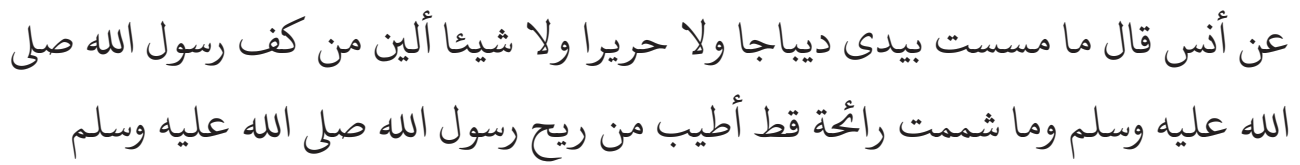

Dari Anas ibn Malik: Aku tidak pernah menyentuh sutra dan selainya yang lebih lembut kecuali telapak tangan Rasulullah saw, dan aku tidak pernah mencium wangi yang terlebih wangi kecuali wangi Rasulullah saw.

Sedangkan hadis musalsal berjabat tangan dari riwayat Abu al-Abbas al-Mu'ammar juga didapat dari gurunya al-Fadani dan Sayyid 'Alwi al-Maliki. Dalam praktiknya, untuk meriwayatkan hadis berjabat tangan ini, seorang murid harus duduk di depan guru dengan cara berjabat tangan, kemudian guru mempraktikkan proses jabat tangan tersebut sesuai dengan apa yang guru itu dapatkan dari guru sebelumnya. Proses jabat tangan ini diiringi dengan pembacaan redaksi matan hadis dan sanadnya. Proses berjabat tangan ini dipraktikkan dari satu generasi ke generasi sebelumnya hingga sampai kepada Rasulullah saw. Sebab dalam sebuah redaksi matan hadisnya yang diriwayatkan tersebut, ada sebuah jaminan surga bagi siapa saja yang bisa berjabat tangan dengan Rasulullah saw melalui perantara dari guru ke guru selanjutnya. Redaksi hadis itu adalah:

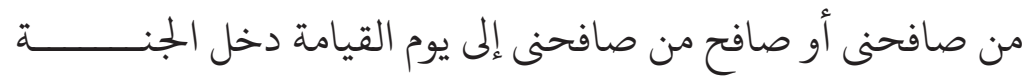

"Siapa yang berjabat tangan denganku atau berjabat tangan dengan orang yang berjabat tangan denganku sampai hari kiamat, niscaya ia masuk surga”

Ulama al-Banjari ketiga yang aktif dalam transmisi hadis musalsal dalam karyanya adalah Nurdin Marbu. Ulama al-Banjari generasi mutakhir ini dikenal banyak mempunyai berbagai sanad. Hal ini tidak bisa dilepaskan dari rihlah 
'ilmiyyahnya yang memang sedari kecil sudah berada di Mekkah, tepatnya di Madrasah Saulatiyyah. Dalam karyanya yang ditulis dengan judul al-Ahadith alMusalsalat ini dihimpun 33 sanad hadis musalsal. Dan menariknya adalah bahwa kesemua jalur sanadnya tesebut diambil dari musnid al-dunya al-Fadani. Ketiga riwayat hadis, yaitu 1) Musalsal berkasih sayang; 2) Berjabat tangan riwayat Anas ibn Malik; 3) Berejabat tangan riwayat Abu al-'Abbas al-Mu'ammar, kesemuanya itu sama jalur sanadnya dengan apa yang didapatkan oleh ulama al-Banjari lainnya, semisal Syukeri Unus dan Fahmi Zamzam.

Inilah yang disebut dengan tradisi ta'lif al-rijal, sebuah metode yang digunakan untuk mentransmisikan hadis dengan cara langsung mempraktikkan tata cara bentuk periwayatan sebagaimana yang telah dipraktikkan dari satu generasi ke generasi selanjutnya hingga sampai kepada Nabi muhammad saw. Masing-masing dari ketiga ulama al-Banjari tersebut telah melakukan aktifitas transmisi semacam ini, hal ini dibuktikkan dengan adanya 'tempat mengajar' yang mereka dirikan. Syukeri Unus fokus di dua majelis taklimnya, yaitu majelis taklim yang dikhususkan kepada santri Pondok Pesantren Darussalam Martapura yang namanya sabil al-anwar al-mubarak dan dar al-shakirin. Sedangkan Fahmi Zamzam menghidupkan tradisi semacam ini di Pondok Pesantren Yasin, Guntung Manggis, Banjarbaru. Adapun Nurdin Marbu menghidupkan tradisi itu di Pondok Pesantrennya yang didirikannya di Bogor yang bernama ma'had al-zeyn li tafaqquh fi al-din, yang mayoritas santrinya adalah masyarakat berasal dari Banjar.

\section{Penutup}

Dari uraian di atas ditemukan bahwa dinamika intelektual ulama al-Banjari dalam kajian hadis begitu pesat perkembangannya. Jika selama ini kajian-kajian corak keislaman di masyarakat Banjar hanya berkisar pada perkembangan pola kajian tawasuf, fikih, dah tauhid, maka penelitian ini hadir sebagai jawaban bahwa tradisi intelektual ulama al-Banjari begitu berkembang. Perkembangan tersebut dapat dilihat dari beberapa indikasi yang telah ditemukan. Dengan menggunakan pendekatan kajian sejarah intelektual, penelitian ini mengungkapkan bahwa perkembangan kajian hadis dari generasi ke generasi menampilkan perkembangan intelektual yang dinamis. Dari yang mulanya hadis sebagai landasan normatif saja, kemudian berkembang menjadi sebuah kajian-kajian komprehensif yang disajikan dengan beragam bentuk modelnya.

Temuan ini berangkat dari pembacaan yang komprehensif terhadap karya-karya hadis yang terpublikasi karya ulama al-Banjari, baik yang dicetak 
Millatī, Journal of Islamic Studies and Humanities, Vol. 2, No. 2, Des. 2017: 169-194

secara lokal, maupun yang masih berbentuk naskah-naskah pribadi.

Perkembangan tradisi intelektual ini tidak bisa dilepaskan dari peran para ulama Timur Tengah yang membentuk pola pikir dan corak keislaman ulama al-Banjari.

\section{Daftar Pustaka}

Abdullah, Wan Mohd Shagir. Syeikh Muhammad Arsyad al-Banjari Pengarang Sabil al-Muhtadin. Kuala Lumpur: Khazanah Fathaniyah, 1990.

Ahmad, Khader."Autoriti Hadith dalam Kitab Tasawuf Tulisan Jawi: Satu Kajian Terhadap Kitab Hidayah al-Salikin”, Journal of al-Qur'an Eु Hadith Al-Bayan, Vol. 5, No. 10, (2007), 97-128.

al-Dimyati, Abu Bakr ibn Muhammad Shata. Hashiyat I'anah al-Thalibin. Beirut: Dar al-Fikr, t.th.

al-Makki, 'Abd Allah ibn Salim. al-Imdad fi Ma'rifat 'Uluw al-Hadith. Riyad: Dar al-Tauhid, t.th.

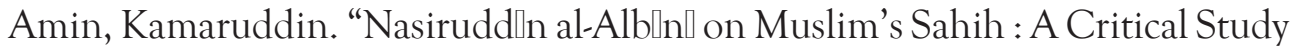
of His Method" Journal Islamic Law and Society, Vol. 11, No. 2 (2004), 149-176. http://www.jstor.org/stable/3399302, diakses pada tanggal 10-6-2015.

Anwar, Khairil. " 'Ulama Indunisiyya al-Qarni al-Thamin 'Ashar: Tarjamah Muhammad Arshad al-Banjari wa Afkaruhu”, Jurnal Studia Islamika, Vol. 3. No. 4, (1996). 137-164.

Azra, Azyumardi. Historiografi Islam Kontemporer, Wacana Aktualitas dan Aktor Sejarah. Jakarta: Gramedia Pustaka Utama, 2002.

Azra, Azyumardi. Jaringan Ulama Timur Tengah dan Kepulauan Nusantara Abad XVII $\mathcal{B}$ XVIII: Akar Pembaharuan Islam Indonesia. Jakarta: Kencana, 2007.

Daud, Alfani. Islam dan Masyarakat Banjar: Diskripsi dan Analisa Kebudayaan Banjar. Jakarta: PT RajaGrapindo Persada, 1997.

Daudi, Abu. Maulana Syeikh Muhammad Arsyad al-Banjari (Tuan Haji Besar) (Martapura: Yayasan Islam dalam Pagar, 2003.

Deraman, Fauzi. "Karya-karya 'Ulum al-Hadith di Nusantara: Satu Sorotan", Journal of al-Qur'an E Hadith Al-Bayan, Vol. 8, No. 10, (2010), 125-149.

'Itr, Nur al-Din. Manhaj al-Naqd fi 'Ulum al-Hadith. Suriah, Dar al-Fikr, 1997.

Majid, Abdul. "Telaah Kritis Terhadap Hadis-hadis Sabil al-Muhtadin" Tesis di Sekolah Pascasarjana Universitas Islam Negeri Syarif Hidayatullah 
Jakarta, 2007.

Muhajirin, Transmisi Hadis di Nusantara: Peran Ulama Hadis Muhammad Mahfudz al-Tarmasi, Disertasi SPs UIN Jakarta, 2009.

Mujiburrahman, "Tasawuf di Masyarakat Banjar: Kesinambungan dan Perubahan

Tradisi Keagamaan", Jurnal Kanz Philosophia, Vol. 3, No.2 (Desember 2013), 153-183.

Munawwar, Nur al-Absar fi Dhikri Nubdhah min Manaqib al-Syeikh Muhammad Kasyf al-Anwar. Martapura: Putra Sahara, t.th.

Munawwar, Risalah al-Samad. Martapura: tp, t.th.

Noor, Yusliani. "Sejarah Perkembangan Islam di Banjarmasin dan Peran Kesultanan Banjar (Abad XV-XIX)”, Jurnal al-Banjari, Vol.11. No. 2. (2012), 239-263.

Rahmadi \& Husaini Abbas, Islam Banjar: Genealogi dan Referensi Intelektual dalam Lintasan Sejarah. Banjarmasin: IAIN Antasari Press, 2012.

Sayeed, Asma. "Women and Hadith Transmission Two Case Studies from Mamluk Damascus”, Journal Studia Islamica No. 95 (2002), 71-94.. Diakses dari http://www.jstor.org/stable/1596142 pada tanggal 11-6-2015.

Voll, John O. "Neo-Sufism: Reconsidered Again" Canadian Journal of African Studies, Vol. 42, No. $2 / 3$ (2008), 314-330. Diakses pada tanggal 1 Mei 2016 melalui : http://www.jstor.org/stable/40380170.

\section{Kitab Hadis Ulama al-Banjari}

al-Banjari, Ahmad Fahmi Zamzam. (2011). al-Awa'il al-Zamzamiyyah al-Banjariyyah. Banjarbaru: Pondok Pesantren Yasin.

al-Banjari, Ahmad Fahmi Zamzam. (2015). 3 Hadis Musalsal. Banjarbaru: Pondok Pesantren Yasin.

al-Banjari, Abdul Wahid. (2012). Tadhkirah al-Lisan min al-Ahadith al-Mawdu'iyyah 'Ala Sayyid al-Bashar. Barabai: Pondok Pesantren Dar al-Hidayah.

al-Banjari, Muhammad Kasyf al-Anwar. (t. th). Tabyin al-Rawi bi Sharh Arba'in al-Nawawi. Martapura: Dar al-Shakirin.

al-Banjari, Muhammad Arsyad. (t. th). Sabil al-Muhtadin litafaqquh Fi Amr al-Din. Singapura: al-Haramayn.

al-Banjari, Muhammad Arsyad. (t. th). Tuhfat al-Raghibin fi Bayan Haqiqat Iman al-Mu'minin. Martapura: Dar al-Shakirin.

al-Banjari, Muhammad Nur al-din Marbu al-Makki. (1996). al-Ahadith al- 
Millatī, Journal of Islamic Studies and Humanities, Vol. 2, No. 2, Des. 2017: 169-194

Musalsalah. Kairo: Majlis Ihya al-Kutub al-Turath al-Islamiy. al-Banjari, Muhammad Sya'rani 'Arif. (t. th). Hidayat al-Zaman fi Ahadiht Akhir al-Zaman. Martapura: Pondok Pesantren Darussalam.

al-Banjari, Muhammad Sya'rani 'Arif. (t. th). Tanwir al-Tullab fi Mustalah al-Hadith. Martapura: Pondok Pesantren Darussalam.

al-Banjari, Muhammad Syuker Unus. (t. th). Dalil al-Thalibin fi Ma'rifat Asma al-Hadith. Martapura: t.p.

al-Banjari, Muhammad Syuker Unus. (t. th). Hadith al-'Arba'in fi al-'ilm. Martapura, Dar al-Shakirin.

al-Banjari, Muhammad Syukeri Unus. (t. th). Ni'mat al-Juwad li Thalib al-Isnad li kutub al-Sittah. Martapura: Dar al-Shakirin. 